\title{
Prospects of Electric Vehicles in the Automotive Industry in Nigeria
}

\author{
Olabode Agunbiade, \\ Department of Economics, University of Abuja, Abuja, Nigeria \\ Peter Siyan, \\ Professor of Economics, Department of Economics, \\ University of Abuja, Abuja, Nigeria
}

URL:http://dx.doi.org/10.19044/esj.2020.v16n7p201

\begin{abstract}
This exploratory study of the prospects of Electric Vehicles (EVs) in Nigeria was necessitated by developments in the global automotive industry, where the proportion of EVs to total vehicle sales is growing significantly. This importance of EVs arose because of the need for efficient, clean and environmentally-friendly vehicles, given the need to shift away from reliance on wasting energy sources to power vehicles. The study relied exclusively on secondary data sourced from academic journals, industry figures and government publications. EVs are of nascent interest in Nigeria, with their potential introduction still being subjected to scrutiny and public discourse. The global EV market is dominated by China and some European countries where deadlines have been set for moving away from internal combustion engine (ICE) vehicles, with the possibility that these disused vehicles may thereafter be imported into Nigerian markets. The impact of the introduction of EVs into the Nigerian market includes the possible reduction of crude oil output and the attendant government revenue generated therefrom, its welcome effect on climate change and public health and less reliance on repairs and maintenance sector of the industry. Challenges revolve around the inadequacy of electricity which is critical for the EVs, procuring inputs like lithium and cobalt and provision of charging facilities and good road network. The study recommended the need for strong policy direction to chart the way forward and devoting resources to Research and Development of EVs.
\end{abstract}

Keywords: Electric Vehicles, Automotive Industry, Automobiles, Nigeria

\section{Introduction}

The manufacturing sector is critical for the economic development of any country, especially emerging ones like Nigeria. Several industrialisation 
strategies have been embarked upon by various regimes in Nigeria towards leading the country into the league of developed nations. Just after political independence in Nigeria in 1960, the Nigerian government recognised this need and embarked on several import substitution industrialisation strategies. An important element of these strategies was the government automotive industry policy in the 1960s and early 1970s, which commenced when private multinational companies introduced Completely Knocked Down (CKD) or Semi-Knocked Down (SKD) automobile assembly plants in the country. Some of these companies include Leventis, UAC, R.T. Briscoe and SCOA (PWC, 2015).

By the 1970s and 1980s, it was the era of the introduction of European Original Equipment Manufacturers (OEMs), who signed agreements with the Nigerian Government to establish state-owned automobile plants across the country. Some of the assembly plants thus established include: Steyr Nigeria Limited, Peugeot Nigeria Limited (PAN) and National Truck Manufacturers (NTM) in the Northern part of Nigeria; Leyland Nigeria Limited and Volkswagen of Nigeria Limited (VON) in the Western part and Anambra Motor Manufacturing Company (ANAMMCO) in the Eastern part.

The original Government strategy was to encourage backward integration with the steel rolling mills being established at that time in Aladja, Ajaokuta and Osogbo (PWC, 2016). Unfortunately, as the country became more and more dependent on the oil sector, the local automobile industry suffered significantly from poor capacity utilisation. This was further exacerbated in the mid-80s, specifically in 1986, with the introduction of the Structural Adjustment Programme (SAP) by the Ibrahim Babangida administration. The programme liberalised the economy of Nigeria and opened the doors wide to all sorts of foreign intervention, especially importation of used items like motor vehicles, locally referred to as 'Tokunbo'.

In the Administration's quest to peg the 'overvalued' national currency at the appropriate rate, the Naira became seriously devalued, thereby making the CKDs and SKDs highly expensive to import. This pushed the prices of the locally assembled cars well beyond the reach of potential car users, who therefore had no choice, but to patronise the fairly used Tokunbo cars imported from Europe and the Americas.

The local assembly plants virtually collapsed and in an effort to jumpstart the sector, the government established the National Automotive Council (NAC) in 1990. The main mandate of NAC was the facilitation of the production of components and vehicles. However, this policy and other later efforts by government did not revive the automobile industry, resulting in the government divesting its interests in the Peugeot and Volkswagen assembly plants. Following the privatisation exercise between 2001 and 2005, these 
companies lost their exclusive right to government patronage, thereby leading to a gradual end of vehicle assembling in the country. In the period prior to 1980 , the eight assembly plants then in operation had a combined capacity of 168,500 units per annum.

In the 1990s, this dropped to approximately $10 \%-20 \%$ of this figure (PWC, 2016). By the year 2005 when Government privatised its ownership interest in PAN and VON, there were virtually no vehicle production in Nigeria. Even though efforts were made recently to rejuvenate the industry with the emergence of Stallion, Innoson, etc. in the vehicle -assembly industry, the glorious past remains an illusion. It is against this background that the recent emergence of electric vehicles in America, Europe and Asia, as replacement for the traditional fuel-powered vehicles, became very relevant to the Nigeria situation and a compelling issue for research.

Electric vehicles are not really a new phenomenon at all. They actually pre-dated the ICE because the pioneer full electric car was manufactured in the 1830s in Europe (Bellis, 2019). What is really new is that with the recent advancement in technology, electric vehicles (EVs) have finally become a viable alternative to fuel-powered vehicles. The EV is an eco-friendly technology, meant to drastically reduce man's reliance on fossil fuel. It is thus a threat to the traditional fuel car market. In a recent report, the World Economic Forum (2018) examined the major developments in the transformation of energy and mobility systems, focusing on the change towards shared mobility and autonomous driving.

The report noted that mobility will transform quite rapidly in the coming years as EVs thrive, ride-sharing continues to develop, and ultimately, autonomous vehicles (AV) would enter urban fleets, especially true for cities where novel forms of transportation are intense and where investment in supportive infrastructure is required to ensure this growth. All these developments will ultimately coincide with the progression towards cleaner, more decentralised and digitalised energy systems, with increasing electrification.

In addition, automakers worldwide are starting to phase out vehicles powered exclusively by fossil fuels as governments seek to confront fuel emissions issues. The growth in electric vehicles (EVs) and hybrid electric vehicles (HEVs) continue climbing, such that by 2025, EVs and HEVs will form about 30\% of all vehicle sales (JP Morgan, 2019). Comparatively, in 2016 , just under 1 million vehicles or $1 \%$ of global auto sales came from plugin electric vehicles (PEVs).

China is undoubtedly the global leader in terms of production and sales of electric cars. By the year 2020, it has been projected that China would account for around $59 \%$ of global vehicle sales, before easing slightly to $55 \%$ by 2025 (JP Morgan, 2019). The popularity of EVs in China has been further 
boosted by the rise of mini-EVs with smaller battery packs made specifically for short-range driving of around 100-150 kilometres (JP Morgan, 2019).

This study is essentially exploratory, since the subject matter is still of recent concern in Nigeria. The paper will rely exclusively on secondary data and is divided into seven sections. The paper proceeds after this introductory section 1 by reviewing conceptual issues in the automotive industry and electric vehicles in section 2, before appraising the global electric vehicle industry in the third section. Section 4 is concerned with developments in the automotive industry and the potential advent of electric vehicles in Nigeria, while section 5 will identify the possible impact of the introduction EVs on the socio-economic situation in Nigeria. The challenges that the introduction of EVs will likely confront in Nigeria are the focus of section 6, before conclusions and policy recommendations are presented in the final section 7 .

\section{Conceptual Issues}

\subsection{Automotive Industry}

The word automotive derives from the Greek words of auto (self) and Latin word motivus (of motion). It is therefore related to self-propelled vehicles or machines. Binder and Rae (2019) described the automotive industry as all organisation and activities concerning the production of motor vehicles, including components, such as engines and bodies, but excluding tyres, batteries, and fuel. Historically, the manufacture of vehicles has evolved globally over the years since 1886, when the first modern car was patented by German inventor, Karl Benz (Deffree, 2018).

Prior to that, Scottish inventor, Robert Anderson invented what can be regarded as the pioneer crude electric carriage powered by non-rechargeable primary cells around 1832-1837 (Bellis, 2019). Since then, there has been tremendous improvements in production methods, quality control, manufacturing systems, computer aided design, branding, business mergers and acquisitions and globalisation. The automobile industry is regarded in any economy as a major instrument for technological and socio-economic advancement, as it serves as an important stimulus for other types of manufacturing activities.

The automotive industry supports upstream industries (steel, mining, oil and gas, metals and plastic), core automotive industries (original equipment manufacturers and component manufacturers) and downstream industries (financial services, marketing, sales, car hire and rentals, transportation and logistics). The raw materials involved in the manufacturing of automobiles are sourced from many industries like iron, steel, glass, aluminum, plastics, carpeting, computer chips and much more. The automotive industry is a regarded as a pillar of the global economy. It is also a major driver of 
macroeconomic growth, stability and technological advancement in many developed and developing countries.

\subsection{Electric Vehicles}

An electric vehicle (EV) has been described as an apparatus which utilises electric motor(s) for propulsion and based on the kind of vehicle, movement may be provided by wheels or propellers driven by rotary motors, or in the case of tracked vehicles, by linear motors (US Department of Energy, 2019). This vehicle employs large traction batteries to power the electric motor. Periodically, the battery pack must be plugged in to a charging station or wall outlet to charge.

Given that it runs on electricity, there are significant differences in the makeup of the electric vehicle, compare to fuel-powered ones. The vehicle does not have provision for the typical liquid fuel components, such as a fuel line, fuel pump or fuel tank and does not emit exhaust as there is no tailpipe. Compared with existing fuel-powered vehicles, electric cars have much simpler design and possess fewer parts; they are more like computers on wheels.

The demand for electric vehicles arose as a result of increase in demand for fuel-efficient, high-performance, and low-emission vehicles. Furthermore, the movement towards reduction in vehicular emission due to strict rules and regulations in several countries is fueling the market growth. Another factor is the phenomenal growth of public charging infrastructure in China, France, Norway, and the other developed countries. However, a major hindrance to the electric vehicle market growth is comparatively the high manufacturing cost of electric vehicles. Technological advancements in electric vehicles and proactive government initiatives will however present significant opportunities for the growth in the electric vehicle market.

\subsection{Types of Electric Vehicle}

According to the Australian Electric Vehicles Association, there are principally three major types of electric vehicles (EVs), based on the extent that electricity is used as their energy source (Australian Electric Vehicles Association, 2019).

\subsubsection{Hybrid Electric Vehicles (HEVs)}

These vehicles powered by both petrol and electricity. In this instance, electric energy is produced by the vehicle's own braking system that recharges the battery and this is referred to as 'regenerative braking'. HEVs start off by utilising the electric motor; thereafter, the petrol engine cuts in as load or speed rises. Both motors are controlled by an internal computer system which ensures the best economy for the driving conditions. 


\subsubsection{Plug-in Hybrid Electric Vehicles (PHEVs)}

Also known as Extended-Range Electric Vehicles (EREVs), these are also powered by both petrol and electricity. The battery is recharged through regenerative braking and 'plugging-in' to an external electrical charging outlet. In EREVs, the petrol engine extends the range of travel of the car by also recharging the battery as it gets low.

\subsubsection{Battery Electric Vehicles (BEVs)}

These are fully electric vehicles, as they are only powered by electricity and do not have petrol engines, fuel tanks or exhaust pipes. Commonly known as 'plug-in' EVs, they utilise external electrical charging outlets to charge their batteries. BEVs can also be recharged through regenerative braking.

In terms of comparison among these three variants, the most discussed and commonest type is the BEV, principally due to its technological advancements and ease of usage with low pollutants.

\section{The Global Electric Vehicle Industry}

In 2017, almost 100 million motor vehicles, including passenger cars, light commercial vehicles, minibuses, trucks, buses, coaches and commercial vehicles were produced worldwide, with a global turnover in excess of $\$ 4$ trillion (OICA, 2017). China is the biggest and the fastest-growing automotive market in the world. In 2016, China's annual vehicle production accounted for nearly 30 percent of worldwide vehicle production and exceeded that of the European Union. It also exceeded that of the United States and Japan combined. (Statistas, 2018). Given such prospects, almost all the major international automakers either have been expanding operations in China or are about to establish plants there in recent years. China's annual vehicle production more or less equals the number of vehicles sold there, with both exports and imports at relatively low levels.

Sadly, the figure for African countries production has been very abysmal, with South Africa leading with 10,000 units in 2017. The total vehicles production capacity in Nigeria as at 2014 was 78,000 with truck assembly capacity of 3,000 and car and bus assembly capacity of 75,000 (Global Auto Industry Market Report, 2015). Nigeria was the 5th largest car market in Africa in 2015 - behind South Africa, Algeria, Egypt and Morocco. (OICA, 2017).

According to the Global Auto Industry Market Report (2015), Africa is considered to be the second fastest growing market for vehicle sales globally. This is as a result of increasing population, which has been forecasted to grow to 1.25 billion by 2025 and to 2.4 billion in 2050 . Moreover, over the past decade, six out of the ten fastest growing countries were from Africa with 
GDP of $4.7 \%$ growth in the Sub-Sahara region as of 2013 (African Development Bank, 2013).

In 2017, the global electric vehicle market was valued at $\$ 119$ billion and is projected to reach $\$ 567$ billion by 2025 , growing at a compound annual growth rate (CAGR) of 22.3\% from 2018 to 2025 (Allied Market Research, 2019). According to the Norwegian Road Federation, a public road infrastructure administration in Norway, pure electric cars and hybrid cars in Norway accounted for 52\% of all new car sales in 2017 as against $40 \%$ in 2016. Norway's parliament has set a resolution goal that by 2025 all cars sold should be zero emissions. The Economist (2019) predicts that electric vehicles will make up $14 \%$ of global car sales by 2025 , up from $1 \%$ today.

China has the largest potential market for EVs, as it has the highest number of electric vehicle manufacturing industries. Chinese automakers manufactured 680,000 all-electric cars, buses, and trucks in 2017. This number was more than the rest of the world's production combined. China produced more than 200,000 all-electric commercial vehicles in 2018, amounting to nearly $5 \%$ of the total output of the world (Allied Market Research, 2019). As at 2018, it was estimated that there were over one billion cars in the world out of which only two million are electric-driven. However, that may soon change; as production costs reduce and governments encourage the adoption of EVs to reduce carbon emissions and confront urban pollution.

Subsequently, some cities have set target years to ban the use of fuelpowered cars to moderate the effect of gaseous emissions from them. Some of these cities include, Oslo (Norway), Madrid (Spain), Hamburg and Berlin (Germany), London (United Kingdom), Copenhagen (Denmark), Paris (France), Brussels (Belgium), Bogotá (Colombia) and New York City (United States of America).

In a report by the International Energy Agency (2019), it was revealed that the sale of electric cars may rise by $24 \%$ annually till 2030 by which time there would be 125 million electric vehicles on the roads, which could further increase to 220 million as strategies to meet global climate goals become operative. It is on record Volvo, a Swedish top vehicle manufacturer, has committed to fitting every car it produced by 2019 with electric or hybrid engines. In the same vein, Germany's BMW plans to mass-produce EVs by 2020, offering 12 models by 2025 .

\section{The Nigerian Situation}

Africa as a whole accounted for less than $1 \%$ of global vehicle production ( 831,000 units) in 2014, based on data supplied by the international carmakers association, Organisation Internationale des Constructeurs d'Automobiles (Automotive Industry Export Council, 2015). South Africa was responsible for producing the bulk of this output. This was followed by 
Algeria, Egypt and Morocco. Nigeria was the 5th largest car market in Africa in 2013 - behind South Africa, Algeria, Egypt and Morocco. These figures exclude nascent assembly operations in a number of countries in Sub-Sahara Africa (SSA).

Apart from South Africa and some North African countries, vehicle production is almost non-existent on the continent. The largest plant in Africa is the 400,000 car per year capacity plant built by Renault in Morocco with a total investment of $€ 1$ billion. The vast bulk of its production is for export to Europe, the Middle East, and North Africa (Automotive Industry Export Council, 2015). Of further interest is the development of the auto industry in Morocco, where Bahija, Malika and Mostapha (2016) studied the level of technology of a subsidiary of a French brand car assembly plant in terms of the level of technology and they discovered that there was massive introduction of new technologies in the workplace.

In order to address the serious decline in the Nigerian automotive market, the National Automotive Design and Development Council (NADDC) was established by Act No. 83 of 30th May 2014 as a result of the merger of the National Automotive Council and the Centre for Automotive Design and Development. It thereafter became a Parastatal of the Federal Ministry of Industry, Trade and Investment (NADDC, 2019a). NADDC has as its major mandate the revitalisation of the auto industry. NADDC estimates annual imports at about 400,000 vehicles (100,000 new and 300,000 used), valued at about US\$3.45billion. Local production capacity of vehicles is estimated about 100,000, with nine (9) firms established to assemble vehicles in Nigeria. However, utilisation has over the years dropped to less than $15 \%$ of installed capacity. Industry experts believe that Nigeria's potential annual new car market could be as high as one million units. However, current new car import is about 56,000 in a used-vehicle dominated market (NADDC, 2019b).

Most locally-assembled vehicles in Nigeria are Chinese models assembled by the Innoson Vehicle Manufacturing Company (IVM) and the recent start of production by the Stallion Group of the Nissan Patrol, although Peugeot Automobile Nigeria Limited intends to commence production of the Peugeot 301brand soon. Nigeria is mainly a used car market with a ratio of new to used cars estimated at about 1:134 (PWC, 2015). The used cars are imported from the United States, United Kingdom, Germany, or through Cotonou in neighbouring Benin Republic by used car dealers and independent sales men and individual buyers.

At the moment, EVs are virtually non-existent on Nigerian roads. Since this is the direction the world is tending to, drastic action needs to be taken to ensure that Nigeria is not left behind. Nigeria must address this important issue. Quite recently, Nigerian Senator Ben Murray-Bruce brought 
the issue of electric cars to national consciousness by sponsoring a Bill, the Electric Cars (Introduction) Bill 2019. The Bill focused on phasing out petroldriven vehicles and introducing electric cars by 2035. The Bill was defeated on the floor of the Senate, with various arguments canvassed against the Bill by the Parliamentarians. Some of the reasons range from the difficulty in forcing the cessation of the use of ICE vehicles and that the introduction of the electric cars would hurt the economy; Nigeria being a major oil producer.

Despite the challenges bedeviling the automotive sector in Nigeria, some assemblers have indicated interest in investing in the manufacturing of electric vehicles (EVs). Over the years, experience has shown that Nigeria usually turns out to be a dumping ground for a variety of banned products. The country stands at a higher risk of dumping when other countries eventually phase out the use of conventional fuel cars. This is due to Nigerians' preference for used vehicles over brand new ones, obviously due to the very poor purchasing power of the majority of the people. It is however noteworthy that an indigenous firm, Nigus Enfinity, has expressed interest in introducing electric vehicles into the Nigerian automobile market in 2018, while its local assembly plant for EVs will become operative by 2020 (Nigerian Investment Promotion Commission, 2018).

\section{Potential Impact of Electric Vehicles in Nigeria}

The introduction of EVs into the Nigerian automotive industry is bound to have some implications, notable among which are the following:

\subsection{Impact on Crude Oil Production}

Relying on data from the Nigerian National Petroleum Corporation (NNPC), Asu (2017) stated that France, India, the Netherlands, China and the United Kingdom (UK) imported almost half of the nation's total exports for the month of May 2017, about 24.4 million barrels of crude oil. It is however noteworthy that these countries are now instituting plans to stop the use of petrol-powered vehicles as part of their efforts to reduce pollution and carbon emissions in their countries. This will definitely affect Nigeria's oil exports in the coming years. More recently, the UK aligned with France in announcing that new fuel-powered cars would be banned by 2040, in order to encourage users to switch over to electric and hybrid vehicles. One of the biggest importers of Nigeria's crude, India, is considering plans to support electrifying all vehicles in that country by 2030 .

\subsection{The impact on government revenue}

By implication, revenues from crude oil, which accounts for over $87.7 \%$ of Nigeria's foreign exchange earnings as at end of 2018 (Okpi, 2018) will be at risk. Given the nation's mono-cultural economy, the global adoption 
of EVs will certainly have a negative impact on government revenue. This development will have long-term economic implications.

\subsection{Repairs and Maintenance}

Electric vehicles are cheaper to run and maintain since they have fewer moving parts. With less things to go wrong, the market for maintenance and spare parts services will shrink. This will have implication on the service and maintenance sector of the auto industry in the country. Electric Vehicles have very few mechanical parts, which translates to the fact that less replacement costs will be required. In addition, because electric vehicles have no engine, obviously there will be no need for regular filter and oil changes making it significantly easier to own and maintain, compared to fuel-powered vehicles.

\subsection{Climate Change}

A major impact of EVs will be to slow the rate of climate change by helping to cut down on $\mathrm{CO}_{2}$ emissions thus improving the air quality. Global warming has become a global concern in recent years due to the burning of fossil fuels. With EVs or 'green cars', the threat of global warming will be minimised.

\subsection{Public Health}

The introduction of EVs cars will improve national public health because one of the greatest negative impacts of internal combustion engines (ICEs) is the exhaust emissions. These emissions smell, are dirty and are filled with harmful gases. Pollutants found in car exhaust emissions can lead to serious health complications like bronchitis and asthma, while chemicals such as benzene and carbon monoxide block oxygen from entering the body's vital organs and may contribute to the causes of some types of cancerous illnesses.

\section{Challenges Facing Introduction of Electric Vehicles in Nigeria}

The following are perceived to be the major challenges to be encountered with the introduction of EVs:

\subsection{Availability of electricity}

This is the paramount challenge that the introduction of EVs will need to confront in Nigeria. The electricity generation, transmission and distribution systems in Nigeria are in dire situation. The regular electricity power outages that the country is used to experiencing cannot augur well for a vibrant EV usage. The highest peak average power supply in recent times was in January 2017 at around 4, $425 \mathrm{MW}$ for a population of around 200 million people (Power Nigeria, 2019). This challenge becomes quite glaring when one compares this situation with that of the second largest economy in 
Africa (South Africa), which produces over 40,000 MW of energy for her 62 million people.

\subsection{Challenges of Lithium and Cobalt}

The Lithium-ion battery was discovered by American Professor, John Goodenough and his associates in 1980, and has proved pivotal for 20th century science and technology (Goodenough \& Park, 2013). It has also become the regular choice for electric cars, which use hundreds of battery cells positioned together in packets that look like metal briefcases, weighing up to $600 \mathrm{~kg}$. Batteries are very complex to produce and contain a delicate mix of chemical materials that must meet a specific list of performance requirements. These batteries are also dependent on cobalt, which has invariably associated the electric vehicle industry with some of the most politically unstable countries in the world. Cobalt supply is dominated by a handful of mining companies, including those in the Democratic Republic of Congo (DRC) and has been linked to wars and condemnable practices like child labour.

\subsection{Charging Facilities for EVs}

This can range from thirty minutes to twelve hours, based on the capacity of the battery and the speed of the charging station. Several companies are already researching into next-generation fast chargers, capable of recharging EVs with a 200 to 300 kilometres range within a reasonable time. A number of charging innovations are being designed, such as wireless charging pads in parking lots, wireless charging under roadways and solar roofs. The major challenge that faced EVs in the past was that they needed battery-replacement stations every 30 kilometres or so (The Economist, 2019). However, rapid gains in battery technology that favour electric motors has drastically improved the situation.

\subsection{Telecommunications}

Improved telecommunications technology and increased connectivity pose the important question of whether it is even necessary to own an automobile, or even to make certain journeys that may be deemed unnecessary.

\subsection{Environmental Concerns}

While it is accepted that the introduction of EVs will reduce $\mathrm{CO}_{2}$ emissions, there is also the environmental issue of battery manufacturing and disposal, which could be quite challenging in Nigeria, where normal domestic waste management system is already an area of concern. These batteries are complex as they contain toxic chemicals; making their disposals at the end of an electric vehicle's life a major environmental challenge. 


\section{Conclusion and Recommendations \\ 7.1 Conclusion}

Nigeria is Africa's largest economy and at the same time the most populous country. These two attributes make her most amenable to enjoy the benefits of technology, innovation and development. However, on the negative side, she is also home to the world's largest concentration of poorest people. This poverty level definitely hinders Nigeria's endeavour to be the leader in developmental attempts in technology, industry, agriculture, trade and so on, in Africa. With so many challenges in infrastructure, security and over-dependence on crude oil, the future of electric vehicles in Nigeria remain seriously uncertain.

This exploratory study has identified the enormous potentials of EVs in Nigeria as a growth and development agent. EVs will certainly revolutionise lifestyle in terms of the way Nigerians work, embark on recreational activities and travels. It will reduce cost, contribute to a cleaner environment and other benefits. What of the supply of equipment and ancillary components to domestic assemblers? What of the distribution system and the wide opportunities for marketers, charging facilities, warehousing facilities, fleet management, logistics and leasing businesses? With the global automotive industry seeking new growth opportunities, it is fair to assume those opportunities will substantially reside in Nigeria, being the continent's largest economy. Hopefully, with the right policies, attitudes and commitment, the future of EVs appear to be bright in Nigeria.

\subsection{Policy Recommendations}

In order to be proactive and embark on appropriate initiatives towards the mass introduction of EVs in Nigeria, the following are recommended:

\subsubsection{Policy Direction}

There is the urgent need for immediate policy action on how to chart the way forward. The failed Bill seeking the legalisation of EVs on the floor of the Senate was introduced rather prematurely. All relevant stakeholders were not yet on board before that critical legislature adventure. Relevant stakeholders like government agencies, policy-makers, regulators, urban planners and manufacturers can collectively define a new paradigm for the mass adoption of EVs. This may involve strong enabling policies and provision of fiscal incentives.

\subsubsection{Enhanced Role for the National Automotive Design and Development Council (NADDC)}

The NADDC was established to fund research into local substitutes since virtually all the components of vehicles are currently imported. They are 
only coupled together in the Nigerian assembly plants. This body must be rejuvenated to work with various stakeholders in the automotive industry in order to remain relevant, given the direction of the global auto industry.

\subsubsection{Research and Development (R \& D)}

Investments in research and development must be encouraged to produce the technological innovations to continually improve EVs. Data and research are vital in the areas of adaptability, viability and relevance. At present, there are essentially no data or research on EV potential being carried on in Nigeria. The movement to an all-electric automobile future will definitely necessitate sizeable investments in R \& D.

\subsubsection{Improved Economy}

The Nigerian economy should be stimulated to improve the disposable income and hence the purchasing power of the middle class that is the ready market for EVs. The middle class of the society has been virtually wiped out due to declining economic conditions.

\subsubsection{Improved and Reliable Infrastructural base}

Improved electricity supply is critical for the success of EVs. So far, the semi-privatisation of the electricity sector has not yielded the required fruits in Nigeria as highlighted earlier. More commitment from both the government and the operators is urgently required in this area. Additionally, other infrastructural support should be enhanced and more developed, especially in the areas of road network and city planning.

\section{References:}

1. African Development Bank (2013). African Economic Outlook: Structural Transformation and Natural Resources. Tunis: ADB

2. Allied Market Research (2019). Electric and Hybrid Vehicles. Retrieved on 21 August, 2019 from: https://www.alliedmarketresearch.com/automotive-andtransportation/electric-and-hybrid-vehicles-market-report

3. Asu, F. (2017). Growing electric vehicle adoption threatens Nigeria's oil exports. Retrieved on 21 August, 2019 from: https://tvcnews.tv/growing-electric-vehicle-adoption-threatensnigerias-oil-exports/

4. Australian Electric Vehicles Association (2019). Types of Electric Vehicles. Retrieved on 17 July 2019 from: http://www.gumtree.com.au/scam-security-centre/buying-ongumtree/the-ultimate-electric-cars-buying-guide/ 
5. Automotive Industry Export Council (2015). South Africa: Automotive Export Manual 2015. AIEC, Arcadia.

6. Bahija, J., Malika, E., \& Mostapha, A. (2016). Electronic Data Interchange in the Automotive Industry in Morocco: Toward the Optimization of Logistics Information Flows. European Scientific Journal, 12(3), 186-196.

7. Bellis, M (2019). History of Electric Vehicles. Retrieved on 21 August, 2019 from: https://www.thoughtco.com/history-of-electric-vehicles1991603

8. Binder, A. K., \& Rae, J. B. (2019). Automotive Industry. Retrieved on $21 \quad$ July, 2019 from: https://www.britannica.com/technology/automotive-industry.

9. Deffree, S. (2018). Karl Benz drives the first automobile, July 3, 1886. Retrieved on 21 July, 2019 from: https://www.edn.com/electronicsblogs/edn-moments/4376656/Karl-Benz-drives-the-first-automobile-July-3--1886.

10. Global Auto Industry Market Report (2015). The African \& Nigerian Automotive Industry Retrieved on 17 July, 2019 from: www.xcomafrica.com

11. Goodenough, J. B., \& Park, K. S. (2013). The Li-Ion Rechargeable Battery: A Perspective. Journal of American Chemical Society, 135(4), 1167-1176.

12. International Energy Agency (2019). Global EV Outlook 2019. Retrieved on 17 July, 2019 from: www.iea.org/publications/reports/globalevoutlook2019/.

13. JP Morgan (2019). Driving into 2025: The Future of Electric Vehicles. Retrieved on 17 July, 2019 from: https://www.jpmorgan.com/global/research/electric-vehicles

14. NADDC (2019a). Positioning Nigeria as one of the leading automotive manufacturing nations in the world. Retrieved on $17 \mathrm{July,}$ 2019 from: http://naddc.gov.ng/about-us

15. NADDC (2019b). Publications. Retrieved on 17 July, 2019 from: http://naddc.gov.ng/publications

16. Nigerian Investment Promotion Commission (2018). Electric Cars to be introduced into Nigerian market by 2018. Retrieved on 21 August, 2019 from: https://nipc.gov.ng/2017/08/25/electric-cars-introducednigerian-market-2018/

17. OICA (2017). 2017 Production Statistics. Retrieved on 17 July, 2019 from: http://www.oica.net/category/production-statistics/

18. Okpi, A. (2018). Africa Check. Retrieved on 21 August, 2019 from: https://africacheck.org/reports/nigerias-economy-services-drive-gdpbut-oil-still-dominates-exports/ 
19. Power Nigeria (2019). Poor Power Supply in Nigeria: What is the Reason? Retrieved on 21 August, 2019 from https://www.powernigeria.com/en/industry-news/poor-power-supply-in-nigeria-what-isthe-reason.html

20. PWC (2015). Nigeria Automotive Industry, Retrieved on 17 July, 2019 from: $\quad$ https://www.pwc.com/ng/en/assets/pdf/africas-nextautomotive-hub.pdf.

21. PWC (2016). Africa's Next Automotive Hub: Reality Check. Retrieved on 23 July, 2019 from: https://www.pwc.com/ng/en/publications/africas-next-automotivehub.html.

22. Statistas (2018). Automobile manufacturing in China. Retrieved on 17 July, 2019 from: https://www.statista.com/topics/1050/automobilemanufacturing-in-china/.

23. The Economist (2019). The Death of the Internal Combustion Engine. $\begin{array}{llll}\text { Retrieved on } 15 & 15\end{array}$ from:https://www.economist.com/leaders/2017/08/12/the-death-ofthe-internal-combustion-engine.

24. US Department of Energy (2019). How Do All-Electric Cars Work? Retrieved on 10 August, 2019 from: https://afdc.energy.gov/vehicles/how-do-all-electric-cars-work

25. World Economic Forum (2018). Electric vehicles for smarter cities: The future of energy and mobility. World Economic Forum, Geneva, Switzerland. 